\section{ROBERT E. AGGER}

Robert E. Agger died at age 80 in September 2007 .

\section{Introduction, by Dan Goldrich}

Bob Agger was a force. A set of us testify to that in the following reflections.

He was committed to the community of his coworkers, always engaged in a center or institute designed for the further development of that community, in which his broad world of fellow students of politics was encouraged to participate. So it seemed important to us that we memorialize him on an appropriately collective basis.

Some of us were his former graduate students, some colleagues, and some coauthors. I think it's safe to say we all consider ourselves to have been mentored by him. Mentoring is a critically important aspect of academic work, yet elusive and too rarely a focal point of inquiry and reflection. The student or younger colleague who lacks mentoring is denied important nurturance.

For me as a new graduate student, I was provided a vantage point from which to watch him as a young professor, living his work-life as a parent-partner with small kids, an active member of the community outside the university-I had a model of a very relevant adult life. The assistantship with him gave me the opportunity to become a member of a research group engaged in an exciting comparative community study with an intriguing natural experimental design. The group itself was embedded in a broad, dynamic social science research institute. The research under Bob's direction enabled me to design and implement a further phase of the work that I developed as a dissertation project.

That led to the years of collective work on The Rulers and the Ruled, and the incomparable experience of arduous conceptualization, design, writing, and rewriting. The whole mentored trajectory helped me to develop the self-confidence I needed for my academic career. Along with all that Bob gave me, The Rulers endeavor provided me the particular pleasure of working through a tough challenge and presenting a solution to him that moved the project forward at a key point. It was just one piece of a complex work, but it provided me the opportunity to demonstrate my grati- tude to him as mentor, and that stands, on reflection, as one of the most satisfying experiences of my work life.

\section{Bert E. Swanson}

Imagine two young professors (1950s), one from the mean streets of Manhattan (Washington Heights), the other from an isolated hollow (Swede) in Northwest Washington. The former was indignant about the social injustices fostered by America's leadership. The latter was curious but far too accepting of assaults upon human dignity. I was shocked by some of his statements such as: "I wouldn't let the Dean clean out my dog-house" (competence), and "I don't read the writings of dead people" (on the need to follow up on the interpretation of puzzling ideas). Bob was an idea person and seemed to know how the polity works (deductive). I was more inductive and thought my strengths were to listen and learn from people from all walks of life, but above all else, apply ideas to the reality of each situation.

His leadership in writing the Rulers and the Ruled was intense (for example, operating Guttmann scaling on an IBM machine with pockets and no counters). It was instructive as he introduced me to the importance of the functions of community power, political ideologies, and social and cultural class, in the formulation of public policy. Historically, it is important to note that our study took place as the scope of American government was expanding; our discovery of the "radical right" captured the beginning of the resistance to, and eventually widespread contraction of, federal support for urban governments as growth machines, the ideology that prevails today. Furthermore, Bob was keen to note the practices of realpolitik and the humbuggery (deceit) that have polarized our modern politics.

These ideas were ever present as I engaged in "political prototyping" (Lasswell), whether in New York City and its suburbs, or in small town revitalization projects in the Northeast and Florida. Bob was a great correspondent with whom I could share my experiences and ideas. My last exchange was about whether the American polity was rigged by deliberate design or inadvertent happenstance.
Not all our time was devoted to the discussion of the politics of injustice. Bob loved to fish for trout on the McKenzie River and salmon in the Pacific. Bob, I'll miss your often expressed indignation and challenges as they are deeply embedded in my mind as I continue to attempt to better clarify my thoughts.

\section{Jerry Medler}

What I learned from Bob Agger was not taught in the classroom.

I first came to know Bob Agger as my "boss." I had been hired with a fresh undergraduate degree to be a research assistant on Bob's current (1963) HEW grant. There were, as I grew to recognize, some "problems" with my appointment. Not the least of which was the fact that I had not yet been formally accepted to the graduate school, then a requisite for being a graduate research assistant. It was a useful, if painful, introduction to the way Bob "administered" his research projects and probably the most valuable lesson I learned from him. For Bob, details such as formal contracts and bureaucratic appointments were secondary. What came first was the research project, or more importantly, the people who were doing it. Administrative improvisation was a daily riff for Bob-something that had to be taken care of, as a prelude to the excitement and camaraderie of "doing" research.

It was an exciting moment to be working with Bob. He was in the process (with coauthors Goldrich and Swanson) of finishing The Rulers and the Ruled. I was given the task of constructing the index for a very long manuscript. Consequently, I read every single word of the manuscript, a record I still claim as unmatched by all other readers. This book went on to win the APSA's Woodrow Wilson Award. I like to think the index was what pushed the Rulers over the top.

At the same time the Mississippi Democratic Freedom Party was seeking to be seated at the 1964 Democratic National Convention. Bob found this challenge irresistible and worked with Oregon senator Wayne Morse to prepare a brief supporting the challenger's position as they sought to replace the old guard party in a credentials committee fight. As a research 
assistant I was asked to help on this project that provided me with a crash course in American political party history and legal research. The larger lesson, of course, was that politics is important; politics is real and affects people's lives; and political scientists can have an effect on political institutions. This was a bedrock position with Bob.

Intellectually, Bob was constantly stretching the theory and the methods of the discipline with his emphasis on comparative analysis guided by the rigor of experimental logic. His use of quasiexperimental designs to capture natural setting experiments was pioneering in political science. Moreover, Bob saw no practical limits to the value of comparative analysis using these ideas to study communities and later comparing national political systems on an international scale. To sustain these ideas Bob took time to build the Institute for Comparative Experimental Research on Behavioral Systems (INCERBS) to house his work and to support a stream of guest scholars as he expanded his intellectual horizons to European political systems. It was both challenging and exciting to work with Bob in this setting. It was also the beginning of the end of our relationship as Bob was soon overtaken by the attractions of these other places that he studied. Bob left the University of Oregon and eventually the United States. Sadly, our paths never crossed again.

\section{Michael Baer}

Bob was a charismatic instructor and excelled in graduate seminars. His goal was to prepare his students for the future, to socialize them into the profession. A central point in his seminars was to engage students in his research, not just in the results, but all aspects: how he obtained the resources to conduct the research, the processes necessary to produce data of high quality, and how the analysis proceeded. He would instruct them in his cynical, yet optimistic, fashion how it was very important to only seek funding for research that was already complete. That, he noted, gave you certainty of success and the flexibility of resources to undertake your next project, which when done, would permit the intelligent seeking of funding. Socialization of his graduate students was so important that Bob organized non-credit "seminars" for students to prepare them as they were leaving graduate work on how to submit grant proposals and how to prepare articles for publication.

Socializing his students was not just preparation for research, but it was also preparation for teaching. Bob loved encouraging every student to challenge him and to challenge each other. In fact he was not hesitant to set up situations where he created arguments between his students, but always with the goal of drawing their ideas out. During the period of his career when he was domiciled in Italy, for almost 10 years he spent one semester each year teaching in Kentucky, first at the University of Kentucky and then at Eastern Kentucky University. Faculty warned him that it was not as easy to get students from Appalachia to interact in class as it was in other regions. This did not deter Bob. Three weeks into one semester, Bob asked a colleague to take over his class for a week while he went to care for his ill mother. The faculty member went in with his 5o-minute lecture and found he could only get through 10 minutes of it as Bob's students, right and left, challenged and questioned virtually every thought, every sentence. Bob had the ability to get students to think, to speak, and to empower them to challenge those they would not have challenged before ... and it did not take him long to do it.

Bob developed an attachment to Appalachia. The two sons he adopted from India during his second marriage spent considerable time during their formative years in Kentucky, becoming citizens of the world: born in the third world, citizens of Italy, and thoroughly versed in the culture and twang of Appalachia. One of his sons returned to Berea College in Kentucky for his undergraduate degree, returning to Italy for his graduate work. Not only did Bob develop an attachment to the universities where he taught in Kentucky, but his entrepreneurial spirit, and Bob was always an entrepreneur, led him to make efforts to link Italian politicians and business people to those in Kentucky. At one time he was trying to develop a "treaty" between the moguls of the coal industry in Appalachia and the politicians of Italy.

Bob always was quick on his feet and exerted his sense of humor. Finishing dinner at the APSA with half a bottle of wine remaining on the table, Bob asked if the waiter could re-cork it and he would carry it away. After it was explained that was not allowed by law, Bob asked if they could re-cork it for his next dinner in the restaurant. The waiter agreed, marked the bottle, and Bob left immediately for the airport and his flight home to Italy.

\section{John Orbell}

I first met Bob Agger in 1966 when I attended a conference on urban politics in Athens, Georgia, which he was attending with some other people from Oregon. His wit, scholarly virtuosity, and personal charisma were all on great display at the conference, and I immediately became an admirer-or, perhaps, follower. He was very hard to resist. When I joined the faculty at Oregon the next year, his institute on the floor below the political science department was a center for bright and interesting people, most of whom were working with him in one way or another. Bob had an intensely personal way of relating to people that was very hard to resist, and as a young assistant professor I found that very flattering. Part of his charm involved his roguish way of pretending that he knew more about any given topic than he did, producing a great and enjoyable argument-until it became clear (as he normally admitted) that he was bluffing just to have fun, and, of course, that it didn't really matter. In those terms he could run circles around most people, certainly me; but even if one "knew" that it was all a game, arguing with Bob forced those willing to give it a go to think clearly, to watch for weaknesses in any stated position, and to be careful for the pounce that one could be certain would be coming at any moment. I was never in Bob's classroom, but he must have taught several generations of students to enjoy the game, to take it seriously while not "really" doing so, and to accept that, under it all, there was a political reality that had to be recognized and dealt with. Ideas might be there mostly for fun, but the political world was not, was very serious, even if it involved, ultimately, games that would be lost. This was a lesson that took me a while to absorb.

I had spasmodic e-mail contact with Bob during the past 10 years or so, and to my amazement he still held the ability to charm, excite, and inspire as he had done 30 years before when I first came to Oregon.

\section{Lois and Ben Bronfman}

Our affection and admiration for Bob began while we were graduates students 
at the University of Oregon. Ben worked on Bob's groundbreaking cross-cultural political participation study and I had glimpses of the controversial Dr. Agger around campus. For several years we heard little of Bob until he "rediscovered" Ben who was then working at Oak Ridge National Laboratory. Bob was "working the angles" looking for funding and he wrote a letter to his ex-graduate student just in case there might be an opportunity. Loyalty, fascination, and genuine affection prevailed and there was money found. From that time until the last few years of his life when he was robbed of his abundant energy and fearful of death, Bob was a force to be reckoned with in our lives, bursting into our daily routines periodically with new ideas to think about, tasks to perform, and the potential of money to be made. For most of this time he was out of the academic life, living in Italy with his wife Simona and their two children, and making his living by brokering deals between whomever and whomever. "Ben! What do you know about co-generation?" he would fax, or later when e-mail came into fashion, "Kid, can you get this construction firm bonded?" Despite our perception of the odds, deals were made and he was able to support his family. He wrote another book and dreamed of creating an international conference center for likeminded liberals on a mountaintop near Montevecchio. His success sometimes spilled over onto us too in the form of new opportunities to work and share our expertise in Italy. Recently I sadly went through my "Bob file." Several inches thick, it was filled with evidence of his intellectual curiosity, his passion and toughness, his sense of humor, chutzpah, and disdain for pretense. He was fiercely true to himself. He was the scrappy survivor, the young boy who left home at 15 and became a merchant marine and eventually ended up at Yale. His focus on the political life never left him, and I learned my most important lessons on politics from him: "Remember, kid, at the top there is just too much money. There will always be corruption. Don't trust the bastards."

Dan Goldrich

Bert E. Swanson Jerry Medler Michael Baer John Orbell Lois and Ben Bronfman

\section{HAROLD S. GUETZKOW}

Dr. Harold Guetzkow, professor emeritus of political science, psychology, and sociology at Northwestern University, passed away on Novermber 11, 2008, in San Jose, California, at age 93. His wife, Lauris, whom he had married in 1944, preceded him in death. He is survived by sons James (Charolette) and Daniel (Diana) Guetzkow, and his daughter Gay (Howard) Ben Tré. In his seven decades of active scholarship, he distinguished himself as a vibrant and path-breaking scholar as well as an incredibly talented mentor.

Harold Guetzkow was born in 1915 in Milwaukee. At the age of 15, Harold accompanied his ailing father to Austria for diagnosis of what turned out to be amyotrophic lateral sclerosis (ALS). During this visit the family traveled throughout Europe, documenting some of his visits with $16 \mathrm{~mm}$ film he took on a black and white movie camera. One such visit was to the battlefields and graveyards that scarred the fields of Verdun, France. This experience led him to be opposed to killing men who might be like himself but fighting for another nationality, and he became interested in the decisions that stood behind war. $\mathrm{He}$ sold the family construction business in Milwaukee, and headed to college.

On his way to freshman orientation at the University of Chicago via the Interurban Electric North Shore Line he met another UC freshman who was to be an important colleague throughout most of his career, Herbert Simon. Harold taught high school biology for several years in Milwaukee after his graduation.

During the Second World War, Harold applied for and received status as a conscientious objector. This was based on a deep conviction of the necessity to evaluate all sides of any serious debate, only making a decision when it was absolutely and abundantly clear which decision was correct. Part of his alternative service duty as a $\mathrm{CO}$ was working in the Civilian Conservation Corps in northern Michigan, near Traverse Bay, Michigan. In the camps as well as public venues along with other COs, he debated the moral, ethical, and religious pros and cons of going to war. In 1943 he began a new set of CO duties, as resident psychologist at the Laboratory of Physiological Hygiene in the Medical School at the University of Minnesota, where he worked for Josef Brozek and Ancel Keys. In anticipation of the end of the war, and the need to return starving civilians to health in Europe and elsewhere, the laboratory used 36 conscientious objectors to conduct the Minnesota Starvation Experiment. This lead to the important work by Keys et alia, The Biology of Human Starvation (1950), as well as Harold's first book, written with P. H. Bowman, Men and Hunger: A Psychological Manual for Relief Workers (1946, Brethren Publishing House, Elgin, Illinois). The Minnesota experiments are widely credited with discrediting the idea that bed rest is a helpful recovery strategy as well as the benefits of high-quality protein versus carbohydrates in recovery diets.

Harold Guetzkow began graduate school in psychology at the University of Michigan after the war, graduating in 1948. His doctoral thesis established the idea of changing context (known as "set") in problem-solving behavior via a series of experiments. After completing his Ph.D., Harold stayed at the University of Michigan as an assistant professor, guiding the Conference Research Project, where he focused on group decision making and information networks in taskoriented committees and groups. During this period, he wrote the classic article "Long Range Research in International Relations," which proposed the linking of divergent "islands of theory," and led to his interest in using simulation as a method of integration as well as experimentation. He said he conceived of the idea of using the simulation for political science while discussing budgetary constraints with physicists over lunch.

At Herb Simon's invitation, in 1950 he joined the faculty at the Carnegie Institute of Technology, directing the Social Science Laboratory and collaborating with Simon, Richard Cyert, and James March on creating the field that came to be known as "organizational theory." Simon would later dedicate his classic book, Models of Man, to Harold. During the early 1950s, summers were spent at the Center for Research on World Political Institutions at Princeton; during this time he wrote his prescient, landmark study, "Multiple Loyalties."

In 1956-1957 a sabbatical at the Center for Advanced Study in the Behavioral Sciences in Palo Alto led to his development of the InterNation Simulation, which became a widespread vehicle for pedagogy and research in world politics, focusing on simulated decision making in a hypothetical world. In 1957 he returned to the shores 